\title{
Rennet-Induced Gelation of Calcium and Phosphate Supplemented Skim Milk Subjected to $\mathrm{CO}_{2}$ Treatment
}

\author{
C. Guillaume, E. Gastaldi, J.-L. Cuq, and S. Marchesseau \\ Joint Research Unit for Agropolymer Engineering \\ and Emerging Technologies, University Montpellier II, \\ 34095 Montpellier Cedex 5, France
}

\section{ABSTRACT}

A Doehlert design was performed to study the effect of calcium and phosphate supplementation at 0 to 25 $\mathrm{mmol} / \mathrm{kg}$ and 0 to $16 \mathrm{mmol} / \mathrm{kg}$, respectively, on the rennet gelation of reconstituted skim milk subjected to $\mathrm{pH}$ reversible $\mathrm{CO}_{2}$ acidification. Supplemented reconstituted skim milk samples were acidified to $\mathrm{pH} 5.80$ by the addition of $\mathrm{CO}_{2}$ under pressure and depressurized under vacuum to restore the initial $\mathrm{pH}$ value. The second-order polynomial models satisfactorily predicted the effect of salt addition on the micellar molar Ca:P ratio and the average diameter of the casein micelles, whereas only trends were used in the analysis of the rennet-clotting behavior of salt-supplemented, $\mathrm{CO}_{2^{-}}$ treated milk. Whether added Ca was the most determinant factor on the micellar molar $\mathrm{Ca}: \mathrm{P}$ ratio, added $\mathrm{Pi}$ (a mixture of $\mathrm{Na}_{2} \mathrm{HPO}_{4}$ and $\mathrm{NaH}_{2} \mathrm{PO}_{4}$ ) was the most determinant factor on the other responses studied, and its effect was most pronounced when Ca was simultaneously added. By comparison with control samples, changes observed in this study were essentially due to salt supplementation and not to the $\mathrm{CO}_{2}$ treatment. Therefore, this $\mathrm{CO}_{2}$ treatment could be considered as an entirely reversible treatment rather than only $\mathrm{pH}$ reversible, and predictions might be applied to untreated milk. In the case of Ca-supplemented milk, the micellar molar Ca:P ratio increased, the average micellar diameter decreased, and the rennet-clotting properties were improved, whereas opposite effects were observed upon Pi supplementation. Since modification of the micellar molar ratio is the result of change in the chemical composition of micellar calcium phosphate, the effect of calcium and phosphate supplementation on the rennet clotting of milk was found to be also dependent on the nature of the interaction between caseins and colloidal calcium phosphate.

Received October 28, 2003

Accepted June 15, 2004.

Corresponding author: C. Guillaume; e-mail: c-guillaume@ univ-montp2.fr.
(Key words: salt addition, colloidal calcium phosphate, rennet gelation, carbon dioxide)

Abbreviation key: CCP = colloidal calcium phosphate, $\mathbf{F R}=$ firming rate, $\mathbf{I M C U}=$ international milk clotting units, MCP = micellar calcium phosphate, MSD = mean standard deviation, RCT = rennet-clotting time, RMSE = root mean square error, RSM = response surface methodology.

\section{INTRODUCTION}

The presence of calcium and inorganic phosphate in milk is essential to produce a homogeneous gel during the renneting process (van Hooydonk et al., 1986b; Zoon et al., 1988), and the addition of calcium chloride is a common practice in cheese making to accelerate the milk enzymatic gelation. This acceleration is due to a combined effect of an increase in calcium concentration and a decrease in $\mathrm{pH}$. If the $\mathrm{pH}$ of milk is kept constant, the addition of $\mathrm{CaCl}_{2}$ does not affect the proteolysis of $\kappa$-casein, but it does influence the aggregation of the casein micelles (Zoon et al., 1988), resulting in a reduction of the rennet-clotting time (RCT). According to Dalgleish (1984), an increase in the ionic Ca content, which occurs upon Ca supplementation of milk, reduces the zeta potential of the casein micelles in favor of the aggregation phase. When milk is supplemented with $\mathrm{Pi}$ (a mixture of $\mathrm{Na}_{2} \mathrm{HPO}_{4}$ and $\mathrm{NaH}_{2} \mathrm{PO}_{4}$ ) before rennet addition, the RCT is delayed, but the storage modulus of renneted gels measured at $3 \mathrm{~h}$ is increased as observed for Ca-supplemented milk (Udabage et al., 2001). These authors suggest that this increase in the storage modulus is caused by an increase in the amount of colloidal calcium phosphate $(\mathbf{C C P})$. The delay in RCT would be caused by the complexion of $\mathrm{Ca}$ with added $\mathrm{Pi}$, resulting in a decrease in the amount of ionic $\mathrm{Ca}$ and consequently an increase in the negative charges of casein micelles. If $\mathrm{Ca}$ is added simultaneously to milk in the same proportion of $\mathrm{Pi}$, the RCT is reduced, but when the amount of added $\mathrm{Pi}$ is greater than the amount of added $\mathrm{Ca}$, the RCT is still delayed (Udabage et al., 2001). 
During milk acidification by injection of $\mathrm{CO}_{2}$ under pressure, some of the physico-chemical properties of casein micelles undergo considerable changes: CCP is solubilized (Gevaudan et al., 1996), and colloidal caseins are dissociated (Chang and Zhang, 1992). Upon release of pressure, the elimination of the acid agent results in a return to the initial $\mathrm{pH}$ value of milk samples. Indeed, regardless of the $\mathrm{pH}$ reached during acidification, carbonation of milk at $5 \pm 1^{\circ} \mathrm{C}$ followed by depressurization under vacuum induces milk $\mathrm{pH}$ to return to its initial value and the amounts of soluble proteins, $\mathrm{Ca}, \mathrm{Mg}$, and $\mathrm{P}_{\mathrm{i}}$ to be restored (Gevaudan et al., 1996; Guillaume et al., 2004). However, the buffering curves of depressurized milk that had been $\mathrm{CO}_{2}$-acidified to $\mathrm{pH} 4.90$ were different from those of the original milk. Therefore, depressurization seems to involve the inability to completely reform CCP or to change in its salt form (Gevaudan et al., 1996). On the other hand, Guillaume et al. (2004) found no difference in the buffering properties of both the depressurized sample that had been $\mathrm{CO}_{2}$-acidified to $\mathrm{pH} 5.80$ and the untreated sample. Under these conditions, CCP appears to remain unchanged after the $\mathrm{CO}_{2}$ treatment.

In the present study, $\mathrm{CO}_{2}$ acidification to $\mathrm{pH} 5.80$ was performed at $4^{\circ} \mathrm{C}$ on reconstituted, salt-supplemented, and $\mathrm{pH}$-adjusted skim milk samples in a laboratory carbonation pilot plant. After depressurization under vacuum, the initial $\mathrm{pH}$ value of all samples was restored. The aim of this research was to predict the effect of $\mathrm{Ca}$ and $\mathrm{Pi}$ supplementation on the rennet-clotting properties of $\mathrm{CO}_{2}$-treated milk by using response surface methodology (RSM). Moreover, since this pH-reversible treatment appeared not to affect the mineral and protein partition of salt-supplemented skim milk (Guillaume et al., 2002), the work described here is also aimed at evaluating the effect of the reversibility of the carbonation process on the rennet-clotting properties of salt-supplemented skim milk.

\section{MATERIALS AND METHODS}

\section{Milk Preparation}

A low heat type of skim milk powder was obtained from a French dairy manufacturer (U.C.L. Isigny Ste Mère, Isigny Ste Mère, France) and contained 5.53\% total nitrogen, $0.37 \%$ nonprotein nitrogen, $28.10 \%$ casein, $1.26 \%$ calcium, $0.98 \%$ phosphorus, and $50.10 \%$ lactose (all expressed in wt/wt). Skim milk was reconstituted at $12 \%(\mathrm{wt} / \mathrm{wt}$ ) in deionized water in order to be close to industrial acidification processes. Sodium azide $(0.2 \mathrm{~g} / \mathrm{kg})$ was added to prevent bacterial growth. The mineral stock solutions used were $250 \mathrm{mM} \mathrm{Ca}$ (prepared from anhydrous $\mathrm{CaCl}_{2}$ ) and $200 \mathrm{mM} \mathrm{Pi}, \mathrm{pH} 8$ (composed of a mixture of $\mathrm{K}_{2} \mathrm{HPO}_{4}$ and $\mathrm{KH}_{2} \mathrm{PO}_{4}$ ). The salt solutions were added to milk during reconstitution at a concentration ranging from 0 to $25 \mathrm{mmol} / \mathrm{kg}$ of milk for calcium and 0 to $16 \mathrm{mmol} / \mathrm{kg}$ of milk for phosphate, and then the $\mathrm{pH}$ was adjusted to $6.65 \pm 0.02$ for all samples by the addition of $1 \mathrm{~N} \mathrm{NaOH}$ or $1 \mathrm{~N} \mathrm{HCl}$. After stirring for $1 \mathrm{~h}$ at $20^{\circ} \mathrm{C}$, the samples were left to equilibrate overnight at $4^{\circ} \mathrm{C}$. Without any supplementation, the $\mathrm{pH}$ of the reconstituted skim milk was $6.65 \pm 0.02$; its mineral composition is reported in Table 1.

\section{$\mathrm{CO}_{2}$ Treatment of Samples}

Cooled reconstituted skim milk (12\% wt/wt) was poured into the laboratory carbonation pilot plant and pressurized by injection of $\mathrm{CO}_{2}$ with stirring (high pressure gearing pump, Micropump Corp., Vancouver, WA) at $4 \pm 1^{\circ} \mathrm{C}$ until the $\mathrm{pH}$ dropped to 5.80 . The $\mathrm{pH}$ was measured with a high pressure combination probe (Dynaprobe II, Broadley-James Corp., Santa Ana, CA). After a contact time of $15 \mathrm{~min}$, the vat was depressurized, and the milk was racked. At this stage, the $\mathrm{pH}$ of the milk was $5.95 \pm 0.05$, in agreement with the measurements of Jordan et al. (1987) and Tomasula et al. (1998). Degassing of the reconstituted milk samples was achieved at $20^{\circ} \mathrm{C}$ under vacuum using a diaphragm pump (Vacuubrand, GMBH-CO, Wertheim, Germany) for $1 \mathrm{~h}$ to allow the $\mathrm{pH}$ to return to its initial value of $6.65 \pm 0.02$ (Gevaudan et al., 1996).

\section{Mineral Analysis}

The skim milk sample was centrifuged at $160,000 \times$ $g$ at $20^{\circ} \mathrm{C}$ for 55 min using a Beckman L7-65 ultracentrifuge (Beckman Instr. France, Gagny, France). The supernatant (soluble phase) was separated from the pellet (colloidal phase). The $\mathrm{Ca}$ and $\mathrm{P}$ contents in the total milk and in the soluble phase were determined in duplicate by inductively coupled plasma spectrometry (Jobin Yvon 24, Jobin Yvon Instr. S.A., Longjumeau, France) according to the method of Park (2000) and expressed in $\mathrm{mmol} / \mathrm{kg}$. The mineral composition of the micellar phase was deduced from the difference between the total milk and the soluble phase (Guillaume at al., 2002). The micellar molar Ca:P ratio was then calculated.

\section{Particle Size Measurements}

The average diameter of casein micelles was measured at $20^{\circ} \mathrm{C}$ by photon correlation spectroscopy on a Malvern Zetasizer 3000 (Malvern Instr., Orsay, France), using a He-Ne laser light $(\lambda=633 \mathrm{~nm})$ and a scattering angle of $90^{\circ}$. To place the micelles in their natural ionic environment, milk samples were diluted 
Table 1. Mineral composition ${ }^{1}$ of reconstituted skim milk at $12 \%$ (wt/wt).

\begin{tabular}{llll}
\hline & $\mathrm{Ca}(\mathrm{mmol} / \mathrm{kg})$ & $\mathrm{P}(\mathrm{mmol} / \mathrm{kg})$ & Molar ratio Ca:P \\
\hline Total milk & $37.43 \pm 0.18$ & $40.68 \pm 0.25$ & $0.92 \pm 0.03$ \\
Micellar phase & $27.20 \pm 0.11$ & $23.82 \pm 0.13$ & $1.14 \pm 0.02$ \\
\hline
\end{tabular}

${ }^{1}$ Mean values of 3 replicates $\pm \mathrm{SE}$.

to $2 \%(\mathrm{v} / \mathrm{v})$ with their own permeate obtained by filtration at $20^{\circ} \mathrm{C}$ through Amicon YM10 membranes (Amicon, Paris, France). Since the distribution of the particle sizes was primarily monodisperse (polydispersity index less than 0.08), the cummulant method was chosen to analyze the auto-correlation function. The diameter of the particles was deduced from the translational diffusion coefficient, according to the Stokes-Einstein relation, by taking into account the values for the viscosity and the refractive index of the diluents evaluated at $20^{\circ} \mathrm{C}$ on a Searle Rheolab viscometer (Physica Messtechnik, Stuttgart, Germany) and on an Abbe OPL refractometer (Levallois, France), respectively. All samples were assayed 10 times.

\section{Rennet Clotting}

The stock calf rennet solution Naturen (Chr. Hansen's Laboratory, Copenhagen, Denmark) contained $61 \%$ chymosin and $39 \%$ pepsin, and its strength was 145 International Milk Clotting Units (IMCU)/mL. The rennet-induced gelation of milk was performed in duplicate for each run: $100-\mathrm{mL}$ samples were tempered at $30^{\circ} \mathrm{C}$ for $1 \mathrm{~h}$ in a thermostated beaker before the addition of $0.025 \%(\mathrm{v} / \mathrm{v})$ of rennet. Measurements of the stiffness, $\mathrm{K}$, were performed at $30^{\circ} \mathrm{C}$ continuously after rennet addition using a Viscoprocess rheometer (Metravib, Ecully, France), as described by Lagoueyte et al. (1995), at a frequency of $10 \mathrm{~Hz}$. At low strain, $\mathrm{K}$ is defined as the stress divided by the strain and expressed in $\mathrm{Pa}$. The time required for the increase in stiffness at values up to $1 \mathrm{~Pa}$ was taken as the RCT, and the slope between RCT and RCT + 30 min was considered as the firming rate (FR).

\section{Experimental Design}

The experimental design adopted was a Doehlert design (Doehlert, 1970) to minimize replication experiments. The 2 independent variables were $\mathrm{X}_{1}$, the concentration of added calcium, and $\mathrm{X}_{2}$, the concentration of added $\mathrm{Pi}$, at 5 and 3 levels, respectively. The complete design consisted of 8 runs including 2 replicates at the central point. Combinations ranged from 0 to $25 \mathrm{mmol} /$ $\mathrm{kg}$ of milk for $\mathrm{X}_{1}$ and from 0 to $16 \mathrm{mmol} / \mathrm{kg}$ of milk for $\mathrm{X}_{2}$. The responses under observation were the micellar molar Ca:P ratio $\left(\mathrm{Y}_{1}\right)$, the average micellar diameter
$\left(\mathrm{Y}_{2}\right)$, the RCT $\left(\mathrm{Y}_{3}\right)$, and the FR $\left(\mathrm{Y}_{4}\right)$. The RCT and the FR were both used to characterize the rennet clotting of salt-supplemented, $\mathrm{CO}_{2}$-treated milk. The actual values of the 2 independent variables and data obtained in each run are given in Table 2.

The data fitted the following second-order equation for all the responses studied:

$$
Y=b_{0}+b_{1} X_{1}+b_{2} X_{2}+b_{12} X_{1} X_{2}+b_{11} X_{1}^{2}+b_{22} X_{2}^{2}
$$

where $b_{0}, b_{1}, \ldots b_{22}$ are regression coefficients, and $X_{1}$ and $X_{2}$ are the coded independent variables. Statistical analyses were performed using the multiple regression of Statview Student software (1991 version, Abacus Concepts, Inc., Berkeley, CA), and response surfaces were drawn using Excel software (2000 version, Microsoft France, Les Ulis, France).

\section{Experimental and Prediction Model Controls}

Separate experiments were performed independently of the experimental design to evaluate the effect of the $\mathrm{CO}_{2}$ treatment and to control model predictions at the extreme levels of enrichment. Indeed, predictions at the extreme levels are misestimated by using a Doehlert design, which is commonly used to optimize responses at the central point. Reconstituted skim milk samples enriched with $\mathrm{Ca}$ and $\mathrm{Pi}$ were prepared in duplicate and separated into 2 fractions, which were taken through the full process with and without $\mathrm{CO}_{2}$, respectively. Products thus obtained were analyzed, and experimental values for $\mathrm{CO}_{2}$-treated and untreated fractions were compared with model predictions.

\section{RESULTS AND DISCUSSION}

\section{Models Quality}

A Doelhert design was used to study the effect of salt addition on some micellar and rennet-clotting properties of $\mathrm{CO}_{2}$-treated milk. Data obtained for each run are summarized in Table 2 and were used to fit the second-order equation to the following responses: the micellar molar Ca:P ratio $\left(Y_{1}\right)$, the average micellar diameter $\left(Y_{2}\right)$, the RCT $\left(Y_{3}\right)$, and the FR $\left(Y_{4}\right)$. The 4 associated models were developed and statistically analyzed as indicated in Table 3. The adjustment quality 
Table 2. Effect of salt addition on some micellar characteristics and rennet clotting of $\mathrm{CO}_{2}$-treated milk.

\begin{tabular}{|c|c|c|c|c|c|c|}
\hline \multirow[b]{2}{*}{ un } & \multicolumn{2}{|c|}{ Variables $^{1}$} & \multirow{2}{*}{$\begin{array}{l}\text { Micellar } \\
\text { molar ratio } \\
\text { Ca: } \mathrm{P}^{2}\end{array}$} & \multirow{2}{*}{$\begin{array}{l}\text { Average micellar } \\
\text { diameter } \\
(\mathrm{nm})^{2}\end{array}$} & \multicolumn{2}{|c|}{ Rennet clotting evaluation } \\
\hline & $X_{1}$ & $X_{2}$ & & & $\mathrm{RCT}(\min )^{2}$ & $\mathrm{FR}(\mathrm{Pa} / \mathrm{min})^{2}$ \\
\hline 1 & 12.50 & 8.00 & 1.20 & 198 & 47 & 0.865 \\
\hline 2 & 25.00 & 8.00 & 1.35 & 195 & 33 & 1.146 \\
\hline 3 & 18.75 & 14.93 & 1.23 & 208 & 79 & 0.618 \\
\hline 4 & 6.25 & 14.93 & 1.11 & 206 & 68 & 0.998 \\
\hline 5 & 0.00 & 8.00 & 1.12 & 206 & 74 & 0.534 \\
\hline 6 & 6.25 & 1.07 & 1.18 & 198 & 39 & 1.357 \\
\hline 7 & 18.75 & 1.07 & 1.36 & 194 & 27 & 1.670 \\
\hline 8 & 12.50 & 8.00 & 1.21 & 197 & 48 & 0.850 \\
\hline
\end{tabular}

of each model was evaluated by the adjusted coefficient of determination ( $R^{2}$ adj). All models appeared adequate, with satisfactory $\mathrm{R}^{2}$ adj values greater than 0.75 and significant $P$ values (Henika, 1982). Root mean square error (RMSE) for the models and mean standard deviation (MSD) for the experiments were chosen to compare predicted and experimental values for each response. As observed in Table 3, whether the predicted values of models $Y_{1}$ and $Y_{2}$ were close to the experimental data, models $Y_{4}$ and $Y_{5}$ must be taken with precaution because their RMSE and MSD values were not in the same range. This was confirmed by performing 2 independent experiments reported in Table 4. Predicted values for models $Y_{1}$ and $Y_{2}$ showed close agreement with experimental data; only trends were respected for model $Y_{3}$, and model $Y_{4}$ appeared to be highly ambiguous at a low salt enrichment level.
The estimated partial regression coefficients for the 4 equations and results of the significance tests of the coefficients are also given in Table 3. Added Ca was the most determinant variable on the micellar molar Ca:P ratio of $\mathrm{CO}_{2}$-treated milk $\left(Y_{1}\right)$ and had a highly significant effect. Guillaume et al. (2002) reported that the micellar mineral and protein concentrations in $\mathrm{CO}_{2}$ treated milk were particularly swayed by the amount of added Ca. However, as shown in Table 3, added Pi was the most important and significant factor that affected the average micellar diameter $\left(Y_{2}\right)$ and the rennet-clotting properties of $\mathrm{CO}_{2}$-treated milk $\left(Y_{3}\right.$ and $\left.Y_{4}\right)$. This suggests that added Ca mainly influences the mineral and protein partition in $\mathrm{CO}_{2}$-treated milk, whereas added Pi appears to affect the "physical" aspects of casein micelles. Table 3 also shows that $\mathrm{Ca}$ and $\mathrm{Pi}$ involved opposite effects on the 4 chosen responses, as

Table 3. Regression coefficients and analysis of variance of the second-order equation ${ }^{1}$ for the 4 responses studied. $^{2}$

\begin{tabular}{lcccc}
\hline Coefficient & $Y_{1}$ & $Y_{2}$ & $Y_{3}$ & $Y_{4}$ \\
\hline$b_{0}$ & 1.205 & 197.560 & 49.000 & 0.858 \\
$b_{1}$ & $0.128^{* * *}$ & $-4.207^{* * *}$ & $-13.833^{* *}$ & $0.193^{*}$ \\
$b_{2}$ & $-0.056^{* * *}$ & $6.570^{* * *}$ & $23.383^{* * *}$ & $-0.407^{* * * *}$ \\
$b_{12}$ & $-0.043^{* *}$ & $3.025^{*}$ & 13.279 & $-0.400^{*}$ \\
$b_{11}$ & $0.028^{*}$ & $3.140^{*}$ & 4.500 & -0.017 \\
$b_{22}$ & 0.009 & $4.914^{* * *}$ & 4.167 & 0.410 \\
$\mathrm{R}^{2}$ adjusted & $0.981^{* * *}$ & $0.866^{* * *}$ & $0.817^{* *}$ & $0.797^{* * * *}$ \\
MSD $^{3}$ & 0.005 & 1.370 & 2.6 & 0.096 \\
RMSE $^{4}$ & 0.007 & 1.327 & 6.1 & 0.126 \\
\hline
\end{tabular}

$* P \leq 0.05$.

$* * P \leq 0.01$.

$* * * P \leq 0.001$.

${ }^{1}$ Equation: $Y=b_{0}+b_{1} X_{1}+b_{2} X_{2}+b_{12} X_{1} X_{2}+b_{11} X_{1}{ }^{2}+b_{22} X_{2}^{2}$, where $X_{1}=$ added calcium and $X_{2}=$ added phosphate.

${ }^{2} Y_{1}=$ micellar molar ratio $\mathrm{Ca}: \mathrm{P}, Y_{2}=$ micellar average diameter, $Y_{3}=$ rennet-clotting time, $Y_{4}=$ firming rate.

${ }^{3}$ Mean standard deviation.

${ }^{4}$ Root mean square error. 


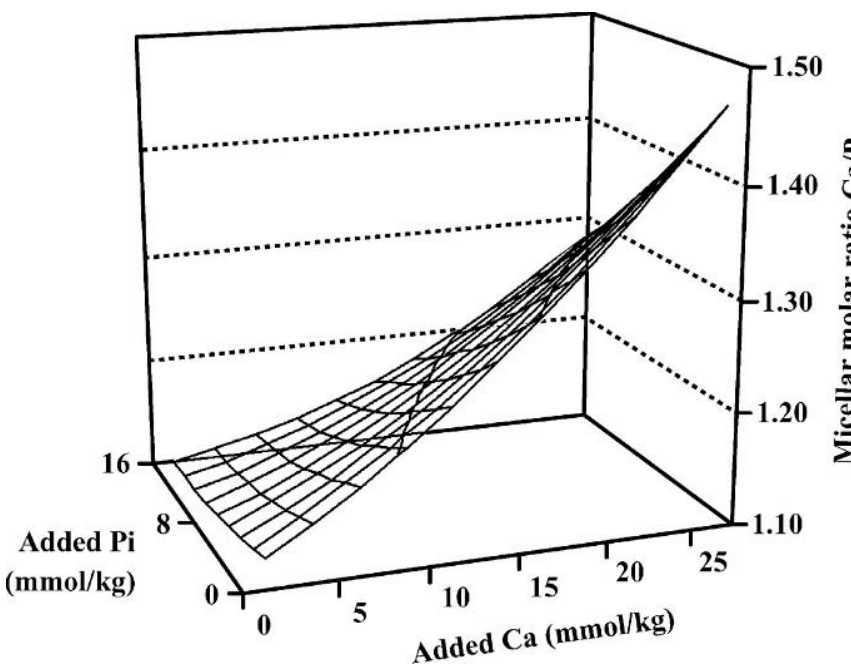

Figure 1. Response surface for the micellar molar ratio Ca:P $\left(Y_{1}\right)$ in salt-supplemented, $\mathrm{CO}_{2}$-treated milk samples.

indicated by the opposite sign of their associated coefficients $b_{1}$ and $b_{2}$, respectively. The relationship between the independent variables and the 4 responses is represented by 3 -dimensional response surfaces (Figures 1, 2,3 , and 4 ).

\section{Micellar Molar Ca:P Ratio}

In native casein micelles, the interaction of caseins with calcium is mainly mediated through phosphorylated amino acid residues and, to a minor extent, by carboxylate groups (Byler and Farrell, 1989). Moreover, Holt (1992) distinguished between micellar calcium

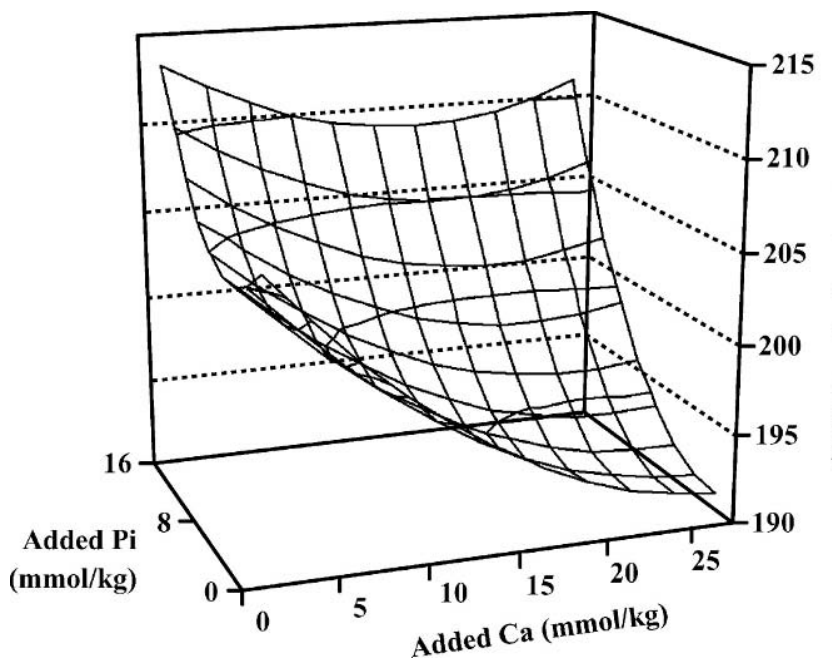

Figure 2. Response surface for the average micellar size $\left(Y_{2}\right)$ in salt-supplemented, $\mathrm{CO}_{2}$-treated milk samples.

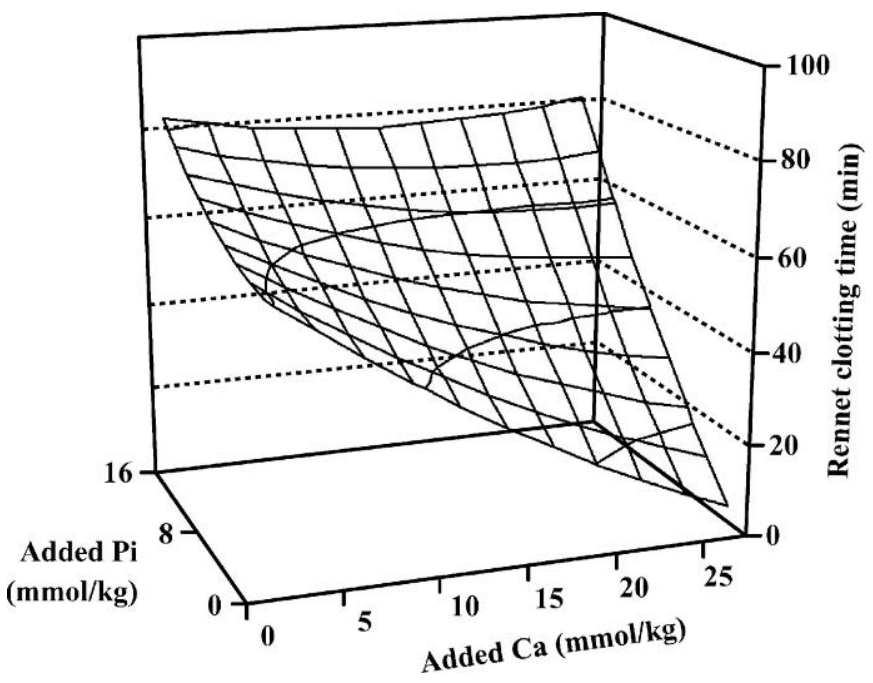

Figure 3. Response surface for the rennet-clotting time $\left(Y_{3}\right)$ in renneted salt-supplemented, $\mathrm{CO}_{2}$-treated milk samples.

phosphate (MCP) considered as the structure in native micelles, including the interacting polypeptide chains, and CCP considered as the small ions in the structure. Therefore, the micellar molar Ca:P ratio $\left(Y_{1}\right)$, where $\mathrm{P}$ represents both $\mathrm{Pi}$ and $\mathrm{Po}$ (inorganic and organic phosphate, respectively), was chosen in this study to follow changes in the chemical composition of CCP and its association with caseins in salt-supplemented, $\mathrm{CO}_{2}$ treated milk. The response surface associated with the model $Y_{1}$ is given in Figure 1 . In the absence of salt addition, the value of the micellar molar $\mathrm{Ca}: \mathrm{P}$ ratio was about 1.13 in $\mathrm{CO}_{2}$-treated milk, which showed close agreement with the value of 1.10 obtained by Holt

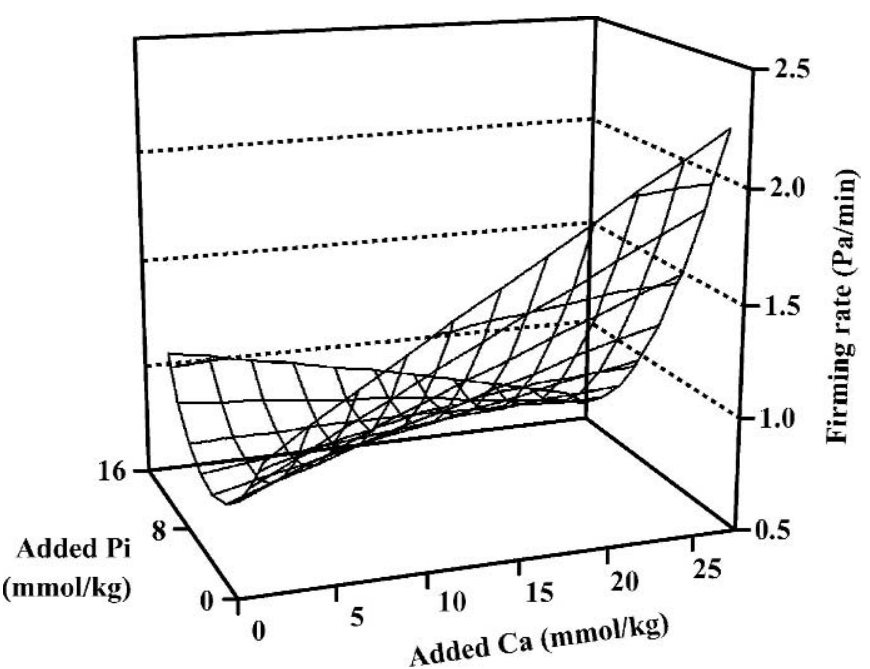

Figure 4. Response surface for the firming rate $\left(Y_{4}\right)$ in renneted salt-supplemented, $\mathrm{CO}_{2}$-treated milk samples. 
(1992) for untreated samples. Upon Ca supplementation, this ratio strongly increased to reach a value of 1.47 at the maximum level of $\mathrm{Ca}$ enrichment. On the contrary, Pi supplementation slightly decreased the micellar molar ratio to 1.10 when $16 \mathrm{mmol} / \mathrm{kg}$ of $\mathrm{Pi}$ was added, and this negative effect was magnified when $\mathrm{Pi}$ was added simultaneously with $\mathrm{Ca}$.

As shown in a previous study, the buffering properties of milk $\mathrm{CO}_{2}$-acidified to $\mathrm{pH} 5.80$ and depressurized under vacuum are similar to untreated samples (Guillaume et al., 2002). Since measurement of the buffering index can be used as a simple method to evaluate changes in MCP (Lucey et al., 1993; Gevaudan et al., 1996), the $\mathrm{CO}_{2}$ treatment should not affect this colloidal salt complex. Therefore, changes in the micellar molar $\mathrm{Ca}: \mathrm{P}$ ratio predicted in salt-supplemented, $\mathrm{CO}_{2}$-treated milk (Figure 1) would be mainly due to salt supplementation. When milk is supplemented with $\mathrm{Ca}$, the amount of CCP is increased (Udabage et al., 2001; Philippe et al., 2003). However, Philippe et al. (2003) found that the micellar molar Ca:Pi ratio remained constant and that the CCP was primarily a dicalcium phosphate-like material, whatever the amount of $\mathrm{Ca}$ added to the milk ( 0 to $13.5 \mathrm{mmol} / \mathrm{kg}$ ). If the chemical composition of CCP remains unchanged, the increase of the micellar molar $\mathrm{Ca}: \mathrm{P}$ ratio predicted for $\mathrm{Ca}$-supplemented, $\mathrm{CO}_{2}$-treated milk would be the consequence of a reduction in the proportion of casein transferred from the soluble to the colloidal phase compared with the ratio of transferred $\mathrm{Ca}$ /transferred $\mathrm{Pi}$, which remains unchanged. Under these conditions, the proportion of phosphoseryl residues in casein micelles would also be reduced. Therefore, we hypothesize that the interaction of CCP with caseins is mediated through carboxylate groups in a more specific way than the native state. On the other hand, when Pi was added, the micellar molar Ca:P ratio decreased, suggesting a shift in the proportion of transferred $\mathrm{Ca}$. This suggests that added Pi integrates the micelles to form CCP by interacting with micellar $\mathrm{Ca}$ ions directly bound to casein.

\section{Average Micellar Diameter}

As shown in Figure 2, the average micellar diameter $\left(Y_{2}\right)$ of $\mathrm{CO}_{2}$-treated milk slightly decreased from 207 to $191 \mathrm{~nm}$ for Ca supplementation from 0 to $25 \mathrm{mmol} /$ $\mathrm{kg}$, whereas it slightly increased to $212 \mathrm{~nm}$ upon the addition of $16 \mathrm{mmol} / \mathrm{kg}$ of Pi. As expected by the significant value of its associated coefficient $b_{2}$ (Table 3 ), the effect of added Pi was predominant. Philippe et al. (2003) found that casein micelles are able to incorporate caseins and ions without detectable changes in their diameter, when milk is supplemented with 0 to 13.5 $\mathrm{mmol} / \mathrm{kg}$ of Ca. According to Udabage et al. (2000), the addition of $\mathrm{Ca}$ or Pi to untreated milk, at 0 to $30 \mathrm{mmol} /$ $\mathrm{kg}$, does not involve changes in the effective diameter of the casein micelles (about $198 \mathrm{~nm}$ ); but when $\mathrm{Ca}$ and $\mathrm{Pi}$ are added simultaneously (at 10 and $30 \mathrm{mmol} / \mathrm{kg}$, respectively), this diameter increases to $209 \mathrm{~nm}$. Regarding the statistical analysis of the associated model $Y_{2}$, variations of the average micellar diameter predicted in salt-supplemented, $\mathrm{CO}_{2}$-treated milk were highly significant and should not be neglected. Moreover, these variations might be correlated with changes in the micellar $\mathrm{Ca}: \mathrm{P}$ ratio, since the micellar size decreased as the micellar Ca:P ratio increased. The addition of Ca to milk (van Hooydonk et al., 1986a) or to phosphocaseinate suspensions (Le Ray et al., 1998) causes an increase in the amount of colloidal $\mathrm{Ca}, \mathrm{Pi}$, and proteins, and a decrease in the water solvation of casein micelles. If we considered that added $\mathrm{Ca}$ integrated the micelles by interacting with phosphoseryl residues but also with carboxylate groups, the concomitant decrease in negative charges inside the casein micelle favored the removal of water solvation, which could involve a decrease in the average micellar diameter. Thus, the addition of Pi to Ca-supplemented milk, which involved an increase in the micellar diameter, would lead to the rehydration of the casein micelles.

\section{Rennet-Clotting Time}

Figure 3 shows the variation in the $\mathrm{RCT}\left(Y_{3}\right)$ of saltsupplemented, $\mathrm{CO}_{2}$-treated milk. Regarding the quality of the model $Y_{3}$ (Table 3), this response surface is only used for analysis of trends. The RCT of $\mathrm{CO}_{2}$-treated milk strongly decreased upon the addition of 0 to 25 $\mathrm{mmol} / \mathrm{kg}$ of $\mathrm{Ca}$, as observed for Ca-supplemented, untreated milk (van Hooydonk et al., 1986b; Zoon et al., 1988). In agreement with previous studies on untreated samples (Lagoueyte et al., 1995; Udabage et al., 2001), $\mathrm{Pi}$ supplementation tended to delay the RCT of $\mathrm{CO}_{2}$ treated milk (Figure 3). According to Udabage et al. (2001), when Ca is added to milk in the same proportion of $\mathrm{Pi}$, the RCT is reduced, but when the amount of added $\mathrm{Pi}$ is greater than the amount of added $\mathrm{Ca}$, the $\mathrm{RCT}$ remains delayed. In our experiment, when $\mathrm{Ca}$ and $\mathrm{Pi}$ were added simultaneously, the effect of the Pi addition appeared to be predominant on the gel formation of renneted $\mathrm{CO}_{2}$-treated milk, and at the maximum level of Pi enrichment (16 mmol/kg), the RCT remained unchanged regardless of the concentration of added $\mathrm{Ca}$. However, this value must be accepted with caution, since it is located at an extreme level of the experimental design and thus is meaningless.

According to Dalgleish (1984), acceleration of the RCT observed in Ca-supplemented milk is related to an increase in the rate of casein micelle aggregation, 
Table 4. Comparison ${ }^{1}$ of some micellar characteristics and rennet-clotting properties between $\mathrm{CO}_{2}$-treated milk, untreated milk, and the predicted milk model at extreme levels of $\mathrm{Ca}$ and $\mathrm{Pi}$ supplementation.

\begin{tabular}{|c|c|c|c|c|c|c|}
\hline \multirow[b]{2}{*}{ Milk } & \multicolumn{2}{|c|}{ Addition $^{2}$ of } & \multirow{2}{*}{$\begin{array}{l}\text { Micellar } \\
\text { molar ratio } \\
\text { Ca:P }\end{array}$} & \multirow{2}{*}{$\begin{array}{l}\text { Average micellar } \\
\text { diameter }(\mathrm{nm})\end{array}$} & \multicolumn{2}{|c|}{ Rennet-clotting evaluation } \\
\hline & $\mathrm{Ca}$ & $\mathrm{Pi}$ & & & $\mathrm{RCT}^{3}(\mathrm{~min})$ & $\mathrm{FR}^{4}(\mathrm{~Pa} / \mathrm{min})$ \\
\hline $\mathrm{CO}_{2}$ treated & $\begin{array}{r}0 \\
25\end{array}$ & $\begin{array}{r}0 \\
16\end{array}$ & $\begin{array}{l}1.16 \\
1.30\end{array}$ & $\begin{array}{l}205 \\
212\end{array}$ & $\begin{array}{l}78 \\
88\end{array}$ & $\begin{array}{l}0.668 \\
0.600\end{array}$ \\
\hline Untreated & $\begin{array}{r}0 \\
25\end{array}$ & $\begin{array}{r}0 \\
16\end{array}$ & $\begin{array}{l}1.14 \\
1.26\end{array}$ & $\begin{array}{l}206 \\
213\end{array}$ & $\begin{array}{l}76 \\
92\end{array}$ & $\begin{array}{l}0.643 \\
0.539\end{array}$ \\
\hline Predicted model & $\begin{array}{r}0 \\
25\end{array}$ & $\begin{array}{r}0 \\
16\end{array}$ & $\begin{array}{l}1.13 \\
1.32\end{array}$ & $\begin{array}{l}207 \\
211\end{array}$ & $\begin{array}{l}61 \\
80\end{array}$ & $\begin{array}{l}1.07 \\
0.6\end{array}$ \\
\hline
\end{tabular}

\footnotetext{
${ }^{1}$ Mean value of 2 replicates.

${ }^{2}$ Expressed in $\mathrm{mmol} / \mathrm{kg}$ of milk.

${ }^{3} \mathrm{RCT}=$ Rennet-clotting time.

${ }^{4} \mathrm{FR}=$ Firming rate.
}

which is mainly caused by the neutralization of the negative charges at the micellar surface due to the high amount of ionic $\mathrm{Ca}$. On the other hand, added Pi would complex ionic $\mathrm{Ca}$ and, as a result, there would be an increase in the number of negative charges at the surface of the casein micelles (Udabage et al., 2001), with a consequence on the delay in the RCT. Since our $\mathrm{CO}_{2}$ treatment appeared to have no effect on the mineral and protein partition of salt-supplemented milk (Guillaume et al., 2002), changes in the ionic environment of casein micelles caused by salt addition to untreated milk should also have occurred in $\mathrm{CO}_{2}$-treated samples.

\section{Firming Rate}

As observed in Figure 4, the shape of the response surface for FR $\left(Y_{4}\right)$ of salt-supplemented, $\mathrm{CO}_{2}$-treated milk is mainly due to $\mathrm{Pi}$ supplementation regarding the high significance of its associated regression coefficient (Table 3). However, no adequacy between the model $Y_{4}$ and the experiment was found at low salt enrichment levels, as indicated in Table 4. Nevertheless, such an adequacy was observed at a high level of salt supplementation. The addition of $\mathrm{Ca}$ appeared to accelerate the firming of renneted $\mathrm{CO}_{2}$-treated milk, whereas $\mathrm{Pi}$ supplementation tended to decrease the FR. It is wellknown that hydrophobic interactions are a primary driving force for rennet gelation. Upon Ca supplementation, we assumed that carboxyl residues were largely included in the MCP, leading to a decrease in water solvation of the casein micelles. This would decrease electrostatic forces within the casein micelles. Opposite effects would be expected to occur upon Pi addition, with a decrease in carboxylate groups in the MCP and an increase in the hydration level of the casein micelle. Therefore, added Ca should act in favor of hydrophobic interactions, and added $\mathrm{Pi}$ should interfere with the establishment of these interactions during formation of the network.

\section{Effect of the $\mathrm{CO}_{2}$ Treatment}

Four experiments were performed at extreme levels of salt supplementation on untreated and $\mathrm{CO}_{2}$-treated milk samples. Results shown in Table 4 suggest that changes observed in this study were essentially due to salt supplementation and not to the $\mathrm{CO}_{2}$ treatment. Depressurization under vacuum restored the initial $\mathrm{pH}$ value and the mineral partition of the $\mathrm{CO}_{2}$-acidifed milk (Gevaudan et al., 1996; Guillaume et al., 2002). However, Gevaudan et al. (1996) found that $\mathrm{CO}_{2}$ acidification to $\mathrm{pH}$ values less than 5.10 had an irreversible effect on MCP, whereas during acid titration, Guillaume et al. (2002) and Guillaume et al. (2004) observed no change in the maximum buffering value of $\mathrm{CO}_{2^{-}}$ treated milk at $\mathrm{pH} 5.80$ or untreated sample. This means that the properties of MCP were unchanged after slight $\mathrm{CO}_{2}$ acidification followed by depressurization under vacuum. By taking into account our results and those reported earlier (Guillaume et al., 2002; Guillaume et al., 2004), $\mathrm{CO}_{2}$ acidification to $\mathrm{pH} 5.80$ followed by depressurization could be considered as an entirely reversible treatment rather than only $\mathrm{pH}$-reversible. Therefore, all the effects observed on the micellar molar $\mathrm{Ca}: \mathrm{P}$ ratio, the average micellar diameter, and the rennet-clotting behavior of $\mathrm{CO}_{2}$-treated milk samples were mainly caused by salt supplementation.

\section{CONCLUSIONS}

This study demonstrates that the mineral balance of milk greatly influenced its rennet-clotting properties. On the contrary, $\mathrm{CO}_{2}$ acidification of milk to $\mathrm{pH} 5.80$ followed by depressurization under vacuum did not modify these properties. Thus, the results obtained on 
salt-supplemented, $\mathrm{CO}_{2}$-treated milk could be applied to the salt-supplemented, untreated samples. The predictions made on Ca-supplemented milk showed that the micellar molar $\mathrm{Ca}: \mathrm{P}$ ratio increased, the average micellar diameter decreased, and rennet gelation was favored, without changes in the enzymatic reaction, as reported by van Hooydonk et al. (1986b). On the contrary, addition of Pi tended to decrease the micellar molar Ca:P ratio, increase the average micellar diameter, and interfere with gel formation during renneting of milk. Upon simultaneous supplementation, Ca was the main factor that influenced the micellar molar $\mathrm{Ca}: \mathrm{P}$ ratio, whereas the effect of $\mathrm{Pi}$ was predominant in the other responses studied.

Native CCP resembles nanoclusters with a spherical core of brushite $\left(\mathrm{CaHPO}_{4}, 2 \mathrm{H}_{2} \mathrm{O}\right)$ units interacting with some phosphopeptide chains, which are the limiting factor in the growth of salt complexes (Holt et al., 1998). Upon Ca supplementation, the increase in the micellar molar Ca:P ratio predicted for $\mathrm{CO}_{2}$-treated milk and the constant value of the micellar molar $\mathrm{Ca}: \mathrm{Pi}$ ratio observed in untreated samples by Philippe et al. (2003) suggest that the growth of CCP is accompanied by a change in its interaction with caseins, i.e., involving a greater number of carboxyl residues than in the native state, which would favor the formation of the network during the renneting process. Indeed, if the number of carboxyl residues is increased in the MCP, the number of negative charges within the casein micelles would be reduced and the micellar water of solvation would be decreased. Both phenomena would lead to a decrease in electrostatic forces in favor of hydrophobic forces during rennet gel formation.

\section{ACKNOWLEDGMENTS}

We are greatly indebted to Sharon L. Salhi for editing the manuscript.

\section{REFERENCES}

Byler, D. M., and H. M. Farrell. 1989. Infrared spectroscopic evidence for calcium-ion interaction with carboxylate groups of casein. J. Dairy Sci. 72:1719-1723.

Chang, M. K., and H. Zhang. 1992. Carbonated milk-proteins. J. Food Sci. 57:880-882.
Dalgleish, D. G. 1984. Measurement of electrophoretic mobilities and zeta potentials of particles from milk using laser Doppler electrophoresis. J. Dairy Res. 51:425-438.

Doehlert, D. H. 1970. Uniform shell design. Appl. Statist. 19:231-239.

Gevaudan, S., A. Lagaude, B. Tarodo de la Fuente, and J. L. Cuq. 1996. Effect of treatment by gaseous carbon dioxide on the colloidal phase of skim milk. J. Dairy Sci. 79:1713-1721.

Guillaume, C., E. Gastaldi, J.-L. Cuq, and S. Marchesseau. 2004. Effect of $\mathrm{pH}$ on rennet clotting properties of $\mathrm{CO}_{2}$-acidified skim milk. Int. Dairy J. 14:437-443.

Guillaume, C., S. Marchesseau, A. Lagaude, and J. L. Cuq. 2002. Effect of salt addition on the micellar composition of milk subjected to $\mathrm{pH}$ reversible $\mathrm{CO}_{2}$ acidification. J. Dairy Sci. 85:20982105.

Henika, R. G. 1982. Use of response surface methodology in sensory evaluation. Food Technol. 36:96-101.

Holt, C. 1992. Structure and stability of bovine casein micelles. Adv. Protein Chem. 43:63-151.

Holt, C., P. A. Timmins, N. Errington, and J. Leaver. 1998. A coreshell model of calcium phosphate nanoclusters stabilized by betacasein phosphopeptides, derived from sedimentation equilibrium and small-angle X-ray and neutron-scattering measurements. Eur. J. Biochem. 252:73-78.

Jordan, P. J., K. Lay, N. Ngan, and G. F. Rodley. 1987. Casein precipitation using high pressure carbon dioxide. N. Z. J. Dairy Sci. Technol. 22:247-256.

Lagoueyte, N., A. Lagaude, and B. Tarodo de la Fuente. 1995. Rheological properties of renneted reconstituted milk gels by piezoelectric viscoprocess: Effects of temperature and calcium phosphate. J. Food Sci. 60:1344-1348, 1363.

Le Ray, C., J. L. Maubois, F. Gaucheron, G. Brule, P. Pronnier, and F. Garnier. 1998. Heat stability of reconstituted casein micelle dispersions: Changes induced by salt addition. Lait 78:375-390.

Lucey, J. A., B. Hauth, C. Gorry, and P. F. Fox. 1993. The acid-base buffering properties of milk. Milchwissenschaft 48:268-272.

Park, Y. W. 2000. Comparison of mineral and cholesterol composition of different commercial goat milk products manufactured in USA. Small Ruminant Res. 37:115-124.

Philippe, M., F. Gaucheron, Y. Le Graet, F. Michel, and A. Garem. 2003. Physicochemical characterization of calcium-supplemented skim milk. Lait 83:45-59.

Tomasula, P. M., N. Parris, W. Yee, and D. Coffin. 1998. Properties of films made from $\mathrm{CO}_{2}$-precipitated casein. J. Agr. Food Chem. 46:4470-4474.

Udabage, P., I. R. Mc Kinnon, and M. A. Augustin. 2000. Mineral and casein equilibria in milk: Effects of added salts and calciumchelating agents. J. Dairy Res. 67:361-370.

Udabage, P., I. R. Mc Kinnon, and M. A. Augustin. 2001. Effects of mineral salts and calcium chelating agents on the gelation of renneted skim milk. J. Dairy Sci. 84:1569-1575.

van Hooydonk, A. C. M., I. J. Boerrigter, and H. G. Hagedoorn. 1986a. $\mathrm{pH}$-induced physicochemical changes of casein micelles in milk and their effect on renneting. 2. Effect of $\mathrm{pH}$ on renneting of milk. Neth. Milk Dairy J. 40:297-313.

van Hooydonk, A. C. M., H. G. Hagedoorn, and I. J. Boerrigter. 1986b. The effect of various cations on the renneting of milk. Neth. Milk Dairy J. 40:369-390.

Zoon, P., T. Vanvliet, and P. Walstra. 1988. Rheological properties of rennet-induced skim milk gels. 3 . The effect of calcium and phosphate. Neth. Milk Dairy J. 42:295-312. 